\title{
FORMULASI BUBUR INSTAN KOMBINASI TEMPE DAN RUMPUT LAUT SERTA EFEK SINERGISMENYA TERHADAP KOLESTEROL DARAH
}

\author{
Syamsuri Syakri ${ }^{*}$, Natsir Djide ${ }^{* *}$, Faisal Attamimi ${ }^{* *}$ \\ *) Fakultas Farmasi Universitas Muslim Indonesia Makassar \\ ${ }^{* *}$ ) Fakultas Farmasi Universitas Hasanuddin Makassar \\ Email : surisweet86@yahoo.com
}

\begin{abstract}
Formulation of Instant Porridge as the combination of Tempe and seaweed and its Synergism Effect Of Cholesterol level Blood. The aim of the research is to make instant porridge as the combination of tempe and seaweed which could be used as a food alternative and its influence on patients cholesterol and the determine a suitable formulation in making instant porridge as the combination of tempe and seaweed. The absorption was measured by using photometer 5010 with a long unbroken wave $546 \mathrm{~nm}$. The statictical analysis reveal that instant porridge as the combination of tempe and seaweed could decrease cholesterol in which decrease of cholesterol really differs among formulation 1,2, and 3. The one in formulation 2 is $50 \%$, and the one formulation 3 is $40 \%$. The effect of synergism occurs in formulation 2, i.e 50\% in which the comparison of tempe and seaweed is $50: 50$. Hedonic test by 10 respondents proves that all the respondents like instant porridge as the combination of tempe and seaweed about colour, aroma, taste, and texture.
\end{abstract}

Key word : Instant Porridge, Formulation, Cholesterol, Seaweed, Tempe

\section{PENDAHULUAN}

Di Indonesia, kedelai telah dikenal sebagai bahan pangan yang biasa diolah menjadi tempe, tahu, tauco, kecap, dan susu kedelai. Selama berabad-abad tempe telah digunakan sebagai bahan pangan sumber protein oleh penduduk di pulau Jawa. Sekarang penggunaannya telah menyebar ke pulau-pulau lainnya di Indonesia, bahkan ke luar negeri. (Muchtadi., 2010).

Tempe merupakan salah satu makanan fermentasi tradisional warisan nenek moyang yang terbukti memiliki nilai gizi yang tinggi dan dapat digunakan sebagai sumber protein yang murah, dan dibuat dari kacang kedelai yang telah dihilangkan selaput (kulit) luarnya, lalu disemaikan dengan suatu jamur tertentu. Rasanya sedikit asam dan berisi lebih banyak serat gizi daripada tahu, tetapi lebih sedikit protein. (Tjay, 2002).

Produksi rumput laut dan sebaran jenisnya banyak dijumpai di seluruh perairan laut di Indonesia. Nilai ekonomis rumput laut ini sangat 
Formulasi Bubur Instan Kombinasi Tempe Dan Rumput Laut Serta Efek Sinergismenya Terhadap Kolesterol Darah

ditentukan oleh kandungan bahan kimianya. Di Indonesia rumput laut diperoleh dari daerah perairan pantai terumbu karang. Habitat pada substrat pasir kasar, pecahan kerang, kerang mati, dan disela-sela kerang hidup. (Kadi, dan Atmadja., 1988).

Begitu banyak potensi gizi yang dimiliki tempe dan rumput laut, namun belum banyak tekhnologi yang menyentuh aspek pengolahan, sehingga tempe hanya sebatas lauk di meja makan. Berbagai potensi yang dimiliki tempe terkadang tertutupi oleh image tempe sebagai makanan kelas bawah.

\section{Kolesterol}

sebenarnya

merupakan lemak yang sangat penting bagi tubuh, tetapi jika berlebihan dapat berdampak negative. Kolesterol dalam tubuh merupakan precursor biosintesis hormone dan asam empedu. Tetapi, peningkatan jumlah kolesterol akan mempercepat terjadinya aterosklerosis yang merupakan resiko utama penyakit jantung koroner yang berujung pada serangan jantung dan kematian. Selain itu, kolesterol juga merupakan pemicu timbulnya berbagai penyakit metabolic, seperti hipertensi, diabetes mellitus, dan stroke.
Membanjirnya produk makanan instan merupakan salah satu tuntutan di masa kini. Setiap orang menginginkan makanan yang dapat dengan mudah dan cepat disajikan dan dinikmati, sehingga perkembangan dan prospek makanan instan masih sangat tinggi. Melihat potensi besar dari tempe dan rumput laut, maka kami tertarik melakukan penelitian tentang Formulasi bubur instan kombinasi tempe dan rumput laut serta efek sinergismenya terhadap kadar kolesterol darah secara invitro.

\section{METODE PENELITIAN}

\section{Bahan dan metode}

Bahan yang digunakan Air suling, asam asetat glasial p.a, asam sulfat pekat p.a, etanol $60 \%$, n-heksan, kalium hidroksida, kolesterol p.a, tempe, rumput laut (Eucheuma $s p$ ), maltodekstrin, natrium klorida $0,9 \%$.

Metode penelitian berupa metode eksperimental laboratorium. Penelitian ini dilaksanakan pada bulan Januari 2011, bertempat di Laboratorium Biokimia Universitas Hasanuddin Makassar, dan Balai Besar Laboratorium Kesehatan Makassar. 
Formulasi Bubur Instan Kombinasi Tempe Dan Rumput Laut Serta Efek Sinergismenya Terhadap Kolesterol Darah

Tabel Rancangan Formula Bubur Instan

\begin{tabular}{cccccc}
\hline No & Nama Bahan & Formula 1 & Formula II & Formula III & Fungsi Bahan \\
\hline 1. & Tempe & $75 \mathrm{~g}$ & $50 \mathrm{~g}$ & $25 \mathrm{~g}$ & Bahan aktif \\
2. & Rumput Laut & $25 \mathrm{~g}$ & $50 \mathrm{~g}$ & $75 \mathrm{~g}$ & Bahan aktif dan \\
3. & Maltodekstrin & $10 \mathrm{~g}$ & $10 \mathrm{~g}$ & $10 \mathrm{~g}$ & Pengental \\
4. & Air & $50 \mathrm{ml}$ & $50 \mathrm{ml}$ & $50 \mathrm{ml}$ & Pelarut \\
\hline
\end{tabular}

Proses Pengolahan Rumput Laut

Sebelum dilakukan proses pengolahan, untuk mendapatkan bahan baku yang bersih perlu dilakukan hal-hal sebagai berikut, rumput laut hasil pemetikan dari alam dibersihkan dari kotoran-kotoran yang menempel seperti pasir, karang, garam dan kotoran lainnya. Setelah bersih dicuci dengan air tawar sampai berwarna putih kemudian dikeringkan. Pencucian dan pengeringan dilakukan beberapa kali sampai diperoleh rumput laut kering yang bersih dan putih. Pengeringan dilakukan dengan penjemuran sinar matahari. Hasil pengeringan rumput laut mempunyai kandungan air berkisar 15-25\%. Setelah kering kemudian rumput laut (25 g, $50 \mathrm{~g}, 75 \mathrm{~g}$ ) dimasak dengan menggunakan $300 \mathrm{ml}$ air sampai mendidih, kemudian di blender.

\section{Proses pembuatan Bubur Instan}

Proses pembuatan bubur instan diawali dengan pemotongan dan penimbangan tempe. Tempe yang sudah dipotong kemudian ditimbang sebanyak 75, 50, 25 g masing-masing formula dan dicampur dengan bahan yang telah terpilih yaitu (hasil perasan rumput laut (25, 50, 75 g), Maltodekstrin $10 \mathrm{~g})$ dengan menggunakan blender. Masukkan 50 $\mathrm{ml}$ air untuk mencampurkan bahan, diaduk sampai merata, Sesudah bahan semuanya tercampur dan menjadi bubur encer, proses pemasakan dilakukan.

Bubur encer dimasak dengan api kecil sambil terus diaduk untuk menghindari gosong. Setelah bubur mengental, bubur didiamkan untuk beberapa saat sampai suhunya turun. Kemudian proses pengeringan dilakukan dengan menggunakan Frezee dryer, setelah kering bubur instan dihaluskan dengan menggunakan blender.

\section{Uji Kadar Kolesterol secara In vitro}

Penentuan Kondisi Penurunan

\section{Kadar Kolesterol}

Ditimbang sebanyak $1 \mathrm{~g}$ bubur instan, disuspensikan ke dalam $2 \mathrm{ml}$ larutan kolesterol etanol (dibuat dengan melarutkan 200 mg kolesterol dalam $100 \mathrm{ml}$ etanol 60\%). Campuran 
Formulasi Bubur Instan Kombinasi Tempe Dan Rumput Laut Serta Efek Sinergismenya Terhadap Kolesterol Darah

tersebut dikocok dan diinkubasi pada suhu $37^{\circ} \mathrm{C}$ selama 1 jam, kemudian di sentrifus pada $4000 \mathrm{rpm}$ selama 5 menit. Kolesterol yang tidak terikat oleh bubur instan dalam supernatan kemudian ditentukan.

\section{Pengukuran Sampel}

Penentuan kolesterol yang tidak terikat ditentukan dengan metode Rudel Morris, yaitu 0,5 ml supernatan ditambahkan $0,6 \mathrm{ml} \mathrm{KOH} \mathrm{33 \%} \mathrm{dan} 6$ $\mathrm{ml}$ etanol $96 \%$ dalam tabung tertutup dan dicampur sempurna. Tabung ditutup kemudian disimpan dalam tangas air suhu $60^{\circ} \mathrm{C}$ selama 15 menit. Setelah didinginkan, ditambahkan $5 \mathrm{ml}$ n-heksan ke dalam tabung dan dikocok sampai tercampur sempurna, kemudian ditambahkan $3 \mathrm{ml}$ air suling, dan dikocok kembali selama 2 menit sampai tercampur sempurna. Lalu $2 \mathrm{ml}$ lapisan heksan dipipet ke dalam tabung uji, pelarut diuapkan. Ditambahkan $0,5 \mathrm{ml}$ larutan $\mathrm{NaCl}$ $0,9 \%$.

\section{Pengukuran Kadar Kolesterol menggunakan Fotometer}

Dimasukkan

reagensia sebanyak $1 \mathrm{ml}$ sebanyak larutan blanko, kemudian diukur dengan fotometer 5010 pada panjang gelombang $546 \mathrm{~nm}$, kemudian dicampurkan standar sebanyak 0,01 $\mathrm{ml}$ dan reagensia sebanyak $1 \mathrm{ml}$ sebagai larutan standar. Larutan ini diukur dengan fotometer 5010 pada panjang gelombang $546 \mathrm{~nm}$, selanjutnya sampel sebanyak $0,01 \mathrm{ml}$ dan reagensia $1 \mathrm{ml}$ di dalam kuvet. Inkubasi selama 10 menit pada suhu $20-25^{\circ} \mathrm{C}$ atau 5 menit pada suhu $37^{\circ} \mathrm{C}$, kemudian diukur dengan fotometer 5010 pada panjang gelombang 546 nm.

\section{Perhitungan Persentase Penurunan Kolesterol}

Perhitungan ditentukan dengan menggunakan rumus,
C - B
$A=\frac{C-B}{C} \times 100 \%$

Dimana $A=\%$ penurunan kolesterol

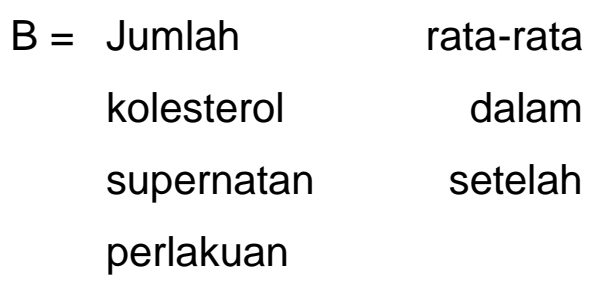

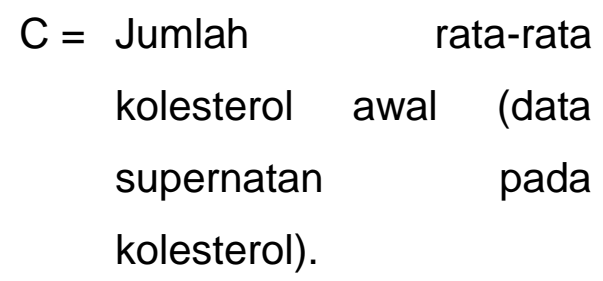

\section{Analisa Data}

Data yang diperoleh dianalisis secara statistika dengan menggunakan Rancangan Acak Lengkap. 
Formulasi Bubur Instan Kombinasi Tempe Dan Rumput Laut Serta Efek Sinergismenya Terhadap Kolesterol Darah

\section{HASIL PENELITIAN}

Dari hasil pengukuran variasi formula bubur instan kombinasi tempe dan rumput laut terhadap penurunan kadar kolesterol diperoleh data sebagai berikut :

\begin{tabular}{cccc}
\hline $\begin{array}{c}\text { Jumlah kolesterol } \\
\text { Awal (mg/dl) }\end{array}$ & $\begin{array}{c}\text { Jumlah kolesterol } \\
\text { akhir (mg/d) }\end{array}$ & $\begin{array}{c}\text { Variasi } \\
\text { Formula }\end{array}$ & $\begin{array}{c}\text { Persentase (\%) } \\
\text { penurunan kadar } \\
\text { kolesterol }\end{array}$ \\
\hline 6,0 & 4,6 & Formula 1 & 23,33 \\
6,0 & 3,0 & Formula 2 & 50 \\
6,0 & 3,6 & Formula 3 & 40 \\
6,0 & 3,6 & Tempe & 40 \\
6,0 & 3,6 & Rumput laut & 40 \\
\hline
\end{tabular}

Tabel 1. Hasil Pengukuran Total kolesterol Tempe

\begin{tabular}{cccc}
\hline No & Perlakuan & Kolesterol awal $(\mathbf{m g} / \mathbf{d l})$ & Kolesterol akhir $\mathbf{( m g / d \mathbf { l } )}$ \\
\hline 1. & Replikasi 1 & 6,0 & 3,0 \\
2. & Replikasi 2 & 6,0 & 4,0 \\
3. & Replikasi 3 & 6,0 & 4,0 \\
\hline
\end{tabular}

Tabel 2. Hasil Pengukuran Total kolesterol Rumput laut

\begin{tabular}{cccc}
\hline No & Perlakuan & Kolesterol awal $(\mathbf{m g} / \mathbf{d l})$ & Kolesterol akhir $(\mathbf{m g} / \mathbf{d l})$ \\
\hline 1. & Replikasi 1 & 6,0 & 3,0 \\
2. & Replikasi 2 & 6,0 & 3,0 \\
3. & Replikasi 3 & 6,0 & 5,0 \\
\hline
\end{tabular}

Tabel 3. Nilai Absorbansi kadar kolesterol oleh variasi formula bubur instan kombinasi tempe dan rumput laut

\begin{tabular}{llcccc}
\hline Perlakuan & Variasi & $\begin{array}{c}\text { Absorbansi } \\
\text { sampel }\end{array}$ & Absorbansi standar & Total & Rata-rata \\
\hline \multirow{2}{*}{ Formula 1 } & Replikasi 1 & 0,004 & 0,205 & \multirow{2}{*}{0,014} & \multirow{2}{*}{0,0046} \\
& Replikasi 2 & 0,006 & 0,205 & & \\
& Replikasi 3 & 0,004 & 0,205 & 0,005 & \multirow{2}{*}{0,003} \\
\multirow{2}{*}{ Formula 2 } & Replikasi 1 & 0,001 & 0,205 & 0,009 \\
& Replikasi 2 & 0,004 & 0,205 & & \\
& Replikasi 3 & 0,004 & 0,205 & \multirow{2}{*}{0,011} & \multirow{2}{*}{0,0036} \\
\multirow{2}{*}{ Formula 3 } & Replikasi 1 & 0,003 & 0,205 & & \\
& Replikasi 2 & 0,004 & 0,205 & & \\
& Replikasi 3 & 0,004 & &
\end{tabular}

Tabel 4. Total Kolesterol Bubur Instan

\begin{tabular}{ccc}
\hline Perlakuan & Variasi & Total Kolesterol $\mathbf{( m g / d \mathbf { l } )}$ \\
\hline \multirow{2}{*}{ Formula 1 } & Replikasi 1 & 4,0 \\
& Replikasi 2 & 6,0 \\
& Replikasi 3 & 4,0 \\
\hline \multirow{2}{*}{ Formula 2 } & Replikasi 1 & 1,0 \\
& Replikasi 2 & 4,0 \\
& Replikasi 3 & 4,0 \\
\hline \multirow{2}{*}{ Formula 3 } & Replikasi 1 & 3,0 \\
& Replikasi 2 & 4,0 \\
& Replikasi 3 & 4,0 \\
\hline
\end{tabular}


Formulasi Bubur Instan Kombinasi Tempe Dan Rumput Laut Serta Efek Sinergismenya Terhadap Kolesterol Darah

Tabel 5. Penurunan Kadar Kolesterol

\begin{tabular}{|c|c|c|c|c|c|c|}
\hline Perlakuan & Variasi & $\begin{array}{c}\text { Kolesterol } \\
\text { awal } \\
(\mathrm{mg} / \mathrm{dl})\end{array}$ & $\begin{array}{c}\text { Kolesterol } \\
\text { akhir } \\
\text { (mg/dl) }\end{array}$ & Total & $\begin{array}{l}\text { Total Rata- } \\
\text { rata }\end{array}$ & $\begin{array}{l}\text { Penurunan kadar } \\
\text { kolesterol (mg/dl) }\end{array}$ \\
\hline \multirow{3}{*}{ Formula 1} & Replikasi 1 & 6,0 & 4,0 & \multirow{3}{*}{14} & \multirow{3}{*}{4,6} & 2,0 \\
\hline & Replikasi 2 & 6,0 & 6,0 & & & 0 \\
\hline & Replikasi 3 & 6,0 & 4,0 & & & 2,0 \\
\hline \multirow{3}{*}{ Formula 2} & Replikasi 1 & 6,0 & 1,0 & \multirow{3}{*}{9,0} & \multirow{3}{*}{3,0} & 5,0 \\
\hline & Replikasi 2 & 6,0 & 4,0 & & & 2,0 \\
\hline & Replikasi 3 & 6,0 & 4,0 & & & 2,0 \\
\hline \multirow{3}{*}{ Formula 3} & Replikasi 1 & 6,0 & 3,0 & \multirow{3}{*}{11} & \multirow{3}{*}{3,6} & 3,0 \\
\hline & Replikasi 2 & 6,0 & 4,0 & & & 2,0 \\
\hline & Replikasi 3 & 6,0 & 4,0 & & & 2,0 \\
\hline
\end{tabular}

\section{PEMBAHASAN}

Kesadaran masyarakat akan pentingnya kesehatan telah meningkat secara nyata dalam dasawarsa terakhir ini. Menurut Goldberg (1994), masyarakat menuntut suatu bahan pangan yang tidak hanya sekedar begizi dan lezat, tetapi juga mempunyai khasiat menguntungkan bagi kesehatan yang dikenal dengan istilah pangan fungsional. Heasman, $M$ dan Mellentin (2001), menyebutkan bahwa pangan fungsional adalah bahan pangan yang mengandung senyawa atau komponen yang berkhasiat bagi kesehatan. Senyawa atau komponen tersebut antara lain serat pangan, oligosakarida, gula alkohol, asam amino, peptida, protein, glikosida, alkohol, isoprenoida vitamin, kolin, mineral, bakteri asam laktat, asam lemak tidak jenuh, dan antioksidan. Pada penelitian ini dilakukan uji invitro penurunan kadar kolesterol oleh bubur instan kombinasi tempe dan rumput laut. Tempe yang merupakan makanan khas Indonesia. Hasil fermentasi Rhizopus oligosporus itu, semakin banyak diminati orang. Senyawa-senyawa aktif yang terkandung dalam tempe sangat baik untuk menurunkan kadar kolesterol dalam darah. Selain itu pula digunakan rumput laut (Sango-sango) yang selain sebagai bahan aktif pada formula ini, juga berfungsi sebagai pengental pada produk tersebut. Kedelai merupakan bahan dasar dalam fermentasi tempe, dimana kedelai yang mengandung zat yang disebut sitosterol dan niasin yang mampu menurunkan kolesterol dan LDL, serta menaikkan HDL (Baraas., 1994). Selain itu pula protein kedelai yang kaya isoflavon dapat meningkatkan aktivitas reseptor-LDL kolesterol.

Mekanisme kerja sitoseterol dan niasin adalah dengan membentuk 
Formulasi Bubur Instan Kombinasi Tempe Dan Rumput Laut Serta Efek Sinergismenya Terhadap Kolesterol Darah

molekul dengan kolesterol yang tidak dapat diserap oleh pencernaan juga mengurangi kolesterol yang bersifat endogen dengan jalan mengikatnya dan diekskresikan melalui alat pencernaan. Penelitian Ziliken menemukan bahwa isoflavon mempunyai sifat anti oksidan, anti adrenalin, anti inflamasi, dan anti aritmia yang mencegah terjadinya denyut jantung yang tidak teratur dan mencegah terjadinya luka endotel dan mampu mengikis endapan kolesterol pada dinding pembuluh darah koroner (Sitope., 1993).

Tempe dan rumput laut dari hasil penelitian memperlihatkan diet tinggi serta larut dapat menurunkan kadar kolesterol. Selain itu, serat larut juga dapat memperbaiki metabolisme karbohidrat. Rekomendasi asupan serat makanan yang dianjurkan adalah 20-30 g per hari untuk orang dewasa, sekitar 6 gram berasal dari serat larut.

Serat terdiri dari komponen serat larut dan serat tidak larut. Serat larut akan menimbulkan perasaan penuh di perut. Serat ini juga mengontrol kadar kolesterol. Selanjutnya oleh Sediaotama, A.D (1999), ditambahkan bahwa serat bahan makanan dapat berperan terhadap pengikatan asam empedu yang diduga sebagai promotor terbentuknya karsinogenesisi. Apabila proses pengikatan itu terjadi dapat menurunkan resiko terjadinya kanker usus besar, dan juga dapat menurunkan kadar kolesterol darah.

Rumput laut telah dikenal sejak puluhan atau bahkan ratusan tahun yang lalu di Indonesia maupun di mancanegara. Pada umumnya rumput laut digunakan sebagai bahan makanan dan minuman, namun seiring dengan berkembangnya IPTEK dewasa ini rumput laut dapat di kembangkan dan manfaatkan dalam berbagai macam industri misalnya tekstil, kosmetik, dan industri kefarmasian. (Syafikri, D., 2005).

Disarankan setidaknya mengkonsumsi tempe minimal $150 \mathrm{~g}$ sehari selama 2 minggu dapat mengurangi total kolesterol darah, LDL kolesterol and total rasio : HDL kolesterol (Agranoff, J., 1999).

Pada pengujian kadar kolesterol darah secara in vitro dilakukan dengan menggunakan alat fotometer 5010, fotometer 5010 khusus digunakan untuk pengukuran kadar kolesterol, trigliserida, LDL, dan HDL. Prinsip kerjanya yaitu sampel dimasukkan ke dalam selang yang menuju kuvet. Sampel akan tinggal dalam kuvet \pm 25 $50 \mu$ l. Sisa sampel akan dihisap oleh pompa roda yang akan diteruskan 
Formulasi Bubur Instan Kombinasi Tempe Dan Rumput Laut Serta Efek Sinergismenya Terhadap Kolesterol Darah

melalui selang tempat pembuangan. Pompa roda akan berputar apabila panel dihidupkan. Sampel yang tinggal di kuvet akan disinari oleh cahaya yang bersumber dari lapu halogen. Cahaya yang dihasilkan oleh lampu halogen yang merupakan sumber cahaya dari alat ini. Cahaya diteruskan hingga mencapai filter, filter merupakan pengatur panjang gelombang. Cahaya yang telah melalui filter akan diteruskan hingga menembus kuvet. Kuvet merupakan tempat sampel yang telah diukur. Cahaya yang melalui kuvet akan diteruskan ke fotodioda. Fotodioda inilah yang merubah cahaya menjadi listrik yang kemudian dapat dicetak sebagai hasil pengukuran.

Pengukuran secara fotometri adalah pengukuran terhadap terjadinya interaksi atom atau molekul dengan radiasi elektromagnetik (REM). Interaksi antara molekul dengan radiasi elektromagnetik dapat menghasilkan efek hamburan, absorbs atau emulsi, radiasi elektromagnetik dapat berupa cahaya, merupakan rangsangan sinar yang dapat diterima oleh mata manusia yang mempunyai panjang gelombang $380-780 \mathrm{~nm}$ dan dikenal sebagai cahaya tampak (visible). Terjadinya interaksi antara radiasi UV-VIS terhadap molekul atau atom mengakibatkan molekul tersebut mengalami transisi elektronik sebagai akibat transisi antara dua tingkat energi electron atau atom yang akan mengakibatkan terjadinya elektron.

Pada penelitian ini dibuat bubur instan dengan menggunakan kombinasi tempe dan rumput laut, ini didasarkan karena tempe dan rumput laut memiliki fungsi untuk menurunkan kolesterol. Dari hasil penelitian setelah dibuat formula bubur instan, menunjukkan bahwa untuk formula 1 memiliki efek dalam menurunkan kolesterol yaitu sebesar 23,33\%, formula 2 sebesar $50 \%$, dan formula 3 sebesar $40 \%$.

Efek sinergisme dalam formula ini dimiliki oleh formula hasil pencampuran tempe dan rumput laut dengan perbandingan $50: 50$, tetapi efeknya sama jika perbandingan tempe dan rumput laut $25: 75$. Sedangkan jika tempe dinaikkan dengan perbandingan 75 , kemudian rumput laut hanya 25, maka kadar kolesterolnya mengalami penurunan sebesar $23,33 \%$, ini dikarenakan serat larut air pada rumput laut lebih tinggi dibandingkan tempe.

Sedangkan untuk hasil analisis statistika menunjukkan bahwa bubur instan kombinasi tempe dan rumput laut dapat menurunkan kolesterol, 
Formulasi Bubur Instan Kombinasi Tempe Dan Rumput Laut Serta Efek Sinergismenya Terhadap Kolesterol Darah

penurunan kolesterol berbeda nyata antara formula 1, 2 dan 3.

Tes hedonik yang telah dilakukan kepada 10 responden, membuktikan bahwa dari segi warna, aroma, rasa, dan tekstur, bubur instan kombinasi tempe dan rumput laut digemari oleh semua reponden.

\section{KESIMPULAN}

Dari penelitian tersebut diperoleh bahwa :

1. Bubur instant kombinasi tempe dan rumput laut dapat menurunkan kadar kolesterol darah.

2. Formula 2 merupakan formula yang paling bagus yang berefek sinergisme terhadap penurunan kadar kolesterol darah sebesar $50 \%$.

3. Hasil analisis statistika menunjukkan bahwa bubur instan kombinasi tempe dan rumput laut dapat menurunkan kolesterol, penurunan kolesterol berbeda nyata antara formula 1,2 , dan 3 .

4. Tes hedonik yang telah dilakukan kepada 10 responden, membuktikan bahwa dari segi warna, aroma, rasa, dan tekstur, bubur instant kombinasi tempe dan rumput laut digemari oleh semua responden.

\section{DAFTAR PUSTAKA}

Agranoff, J, Dr.,.., The Complete Handbook Of Tempe., The American Soybean Association, 1999

Almatsier.S., Prinsip Dasar IImu Gizi., Gramedia Pustaka Utama., Jakarta. 2001

Ambarsari, I., Qanytah., Penerapan Standar Penggunaan Pemanis Buatan Pada Produk Pangan., 2008

Apritna, A., Nutrisi, Nilai per 100 gram Porsi Makanan. (Internet). (Cited 2010 November 28). Available from URL : http: //www.asiamaya.com/nutrient s/rumputlautmentah.htm.
Atmadja,W.S
dan
A.Kadi., Pemanfaatan Alga Laut Di bidang Farmasi, Seminar Pemanfaatan Biota di Bidang Farmasi., Jakarta., Agustus 1989 (Unpublished).

Atmawikarta, A., Komposisi Zat Gizi Makanan Indonesia., Pusat Penelitian dan Pengembangan Gizi., Bogor.,2001

Badan Standarisasi Nasional., SNI Sup Instan (SNI 01-43211996)., Badan Standarisasi Nasional., Jakarta., 1996

Baraas, F.M., Menekan Serangan Jantung dengan Menekan Kolesterol., PT. Gramedia Pustaka Utama., Jakarta., 1994

Bolton, S and Bon, C., Pharmaceutical Statistics Practical and Clinical Applications., Fourth Edition, Revised and 
Formulasi Bubur Instan Kombinasi Tempe Dan Rumput Laut Serta Efek Sinergismenya Terhadap Kolesterol Darah

Expanded., Marcel Dekker, Inc., New York-Basel., 2004

Djide, N., Dr, H, Prof, dan Sartini Dra, M.Si, Apt., Mikrobiologi Farmasi Dasar., Laboratorium Mikrobiologi Dan Biotekhnologi Farmasi, Fakultas Farmasi., Universitas Hasanuddin., Makassar., 2003

Fellows,P.J and Ellis., Food Processing Technology., Priciples and Practice. Ellis Horwood., England., 1992

Granner,D.K.V.W,Rodwell,R.K,murray, and P.A Mayes., Biokimia Harper., Penerjemah: A.Hartono., Penerbit Buku Kedokteran E.G.C., Jakarta., 1979

Hambali, Erliza., Membuat Aneka Olahan Rumput Laut., Jakarta., Penerbit : Swadaya.., 2004

Hartomo , A.J dan M.C Widiatmoko., Emulsi dan Pangan Instan Berlesitin., Andi Offset., Jogjakarta., 1992

Heasman, M, and Mellentin. J., The Function Food Revolution., Healthy People., Healthy Profit., Eartscan Publication Ltd., London., 2001

Hsu,HW,NE Sutton, MO banjo, LD Satterlee dan JG Kendrick., The C-PER assays For Protein Quality., Food Technol., (12):69., 1978

Gyorgy, P.,The Nutritive Value Protein Needs For Infants and Children., Publ. 834.,
National Academy Of Science., Nat Res Council., 181-189. 1961

Istini, S.,___ _., Manfaat dan Pengolahan Rumput Laut., WBL/85/WP-14.

Johnson,A.H, and M.S. Peterson., 1971., Encyclopedi Of Food Technology., The AVI Publ. CO, Wetsport., Connecticut.

Kibbe, H.A., Handbook Of Pharmceutical Excipients., Third Edition., American Pharmaceutical Association Washington,D.C., United kingdom., London., 2000

Matanjun, Patricia ; Suhaila Mohamed; Noordin, M. Mustapha., Nutrient Content Of Tropical Edible Seaweed, Eucheuma Cottonii, Caulerpa Lentilifera and Sargassum Polycystum., 22 Mei 2008. http://www.spiringerlink_jour nal_article.html. Diakses 2 Februari 2011.

Muchtadi, D, Ir, Dr, Prof., 2010., Teknik Evaluasi Nilai Gizi Protein., Penerbit Alfabeta., Bandung.

Muchtadi, D, Ir, Dr, Prof., 2010., Kedelai Komponen Untuk Kesehatan., Penerbit Alfabeta., Bandung.

Murata,K,H Ikehata dan T.Miyatomo., Studies On The Nutritional Value Of Tempe., J.food Sci., 32:580-586 ., 1967

Prangdimurti.E., Metode Evaluasi Nilai Biologis Karbohidrat dan Lemak., Modul e-Learning ENBP., Departemen IImu \& 
Formulasi Bubur Instan Kombinasi Tempe Dan Rumput Laut Serta Efek Sinergismenya Terhadap Kolesterol Darah

Tekhnologi Pangan., IPB., 2007

Rudel,L.,L., and Moris, M.D., Determination Of Cholesterol Using Ophtaldehide., Journal Of Lipid Research 14:364-366., 1973

Sediaoetama, A.D., IImu Gizi Untuk Mahasiswa dan Profesi., Jilid II., Jakarta., Dian Rakyat. 1999

Sitopoe, M., 1993., Kolesterol Fobia., Keterkaitannya dengan Penyakit Jantung., PT. Gramedia., Jakarta.

Soenardi.T., 2002., Makanan Alternatif Untuk Ketahanan Pangan Nsional., Penerbit Buku Kompas., Jakarta.

Stainkraus, KH,DB hand,JP Van Buren dan LR Hackler., 1961., Pilot Plant Studies On Tempeh.,
Proc Conf Soybean

Products For Protein In Human Food., USDA Agric Res Serv., 83-92.

Syafikri, Dedi., Jurnal : Prospek Budidaya Rumput Laut Dalam Mendukung Pembangunan Ekonomi Berbasis Kelautan di Kabupaten Sumbawa. ., 2005

Tjay,T.H., Obat-Obat Penting., PT.Elex Media Komputindo., Jakarta., 2002

Winarno.F.G., 2002.,Kimia Pangan Dan Gizi., PT. Gramedia Pustaka Utama., Jakarta., 1997

Rumput Laut Lezat Dan Menyehatkan, (online) 2010., (http://www/dkp.go.id., Diakses: Sabtu,16 Oktober 2010). 